\title{
SUMMER SEED MORTALITY OF THE PACIFIC OYSTER, CRASSOSTREA GIGAS THUNBERG GROWN IN TOMALES BAY, CALIFORNIA, USA: THE INFLUENCE OF OYSTER STOCK, PLANTING TIME, PATHOGENS, AND ENVIRONMENTAL STRESSORS
}

\author{
COLLEEN A. BURGE, ${ }^{1}$ LINDA R. JUDAH, ${ }^{2,6}$ LOVEDAY L. CONQUEST, ${ }^{1}$ \\ FREDERICK J. GRIFFIN, ${ }^{2}$ DANIEL P. CHENEY, ${ }^{3}$ ANDREW SUHRBIER, ${ }^{3}$ \\ BRENT VADOPALAS, ${ }^{1}$ PAUL G. OLIN, ${ }^{4}$ TRISTAN RENAULT ${ }^{5}$ AND \\ CAROLYN S. FRIEDMAN ${ }^{1 *}$ \\ ${ }^{1}$ School of Aquatic and Fishery Sciences, University of Washington, Box 355020, Seattle, \\ Washington 98195; ${ }^{2}$ University of California Davis, Bodega Marine Laboratory, P.O. Box 247, \\ Bodega Bay, California 94923; ${ }^{3}$ Pacific Shellfish Institute, 120 State Avenue NE \#142, Olympia, \\ Washington 98501; ${ }^{4}$ Sea Grant Extension Program, University of California, Davis, One Shields \\ Avenue, Davis, California 95616; ${ }^{5}$ IFREMER—Laboratoire de Génétique et Pathologie-17390 \\ La Tremblade, France; ${ }^{6} 12$ Grandview Ave, Petaluma, California 94952 (current address)
}

\begin{abstract}
Summer seed mortality (SSM) has occurred yearly in Tomales Bay, California since 1993. SSM has resulted in up to $90 \%$ cumulative losses, and has been associated with extreme temperature, phytoplankton blooms, and an oyster herpesvirus. In this study, three stocks of Pacific oysters were planted at three sites in California (Inner Tomales Bay, Outer Tomales Bay, and Bodega Harbor) in October of 2000 (Fall) and April of 2001 (Spring) and monitored for mortality, growth, and health status. In April of 2001, a similar study was conducted in Totten Inlet, WA state using cohorts of oysters planted in California; animals were monitored for mortality and growth. Temperature data were collected at all sites; phytoplankton abundance data were collected at the California sites. Mortality occurred only at the Inner Tomales Bay site where losses were correlated with maximum temperatures $(r=0.949)$ and preferentially affected faster growing oysters $(r=0.916)$. Significant differences in cumulative mortality were identified among oysters stocks and two of the three oysters stocks planted in the fall outperformed their cohorts planted in the spring $(P<0.0001)$. Microscopic changes in connective tissue and digestive tubules are consistent with previous observations of herpesvirus infections in oysters including: diffuse to multifocal pertibular hemocyte infiltration, diapedesis, dilation of the digestive tubules, nuclear hypertrophy, and chromatin margination. Nuclear hypertrophy and chromatin margination, in particular, are suggestive of herpesvirus infections; these histological changes were rare indicating the need to use multiple diagnostic methods when oyster herpesviruses are suspected to cause SSM. Temperature maxima $\left(\sim 25^{\circ} \mathrm{C}\right)$ experienced at the Inner Tomales Bay site are not considered extreme for Pacific oyster survival; the association between oyster herpesviruses and temperature in Tomales Bay, California is discussed.
\end{abstract}

KEY WORDS: Pacific oysters, Crassostrea gigas, mortality, temperature, oyster herpesvirus, Tomales Bay, California

\section{INTRODUCTION}

Significant recurrent summer losses of the Pacific oyster, Crassostrea gigas Thunberg, have occurred globally for over five decades and concern over its impact on oyster aquaculture has heightened in recent years (Imai et al. 1965, Glude 1974, Perdue et al. 1981, Cheney et al. 2000, Soletchnik et al. 2005). These losses, termed "summer mortality" are typically prolonged and affect older, reproductively mature animals during summer months (Koganezawa 1974, Glude 1974, Cheney et al. 2000). Summer mortality has been associated with multiple stressors including phytoplankton blooms (Cho 1979), warm water temperatures, changes in salinity, dissolved oxygen (Perdue et al. 1981, Perdue 1983), and pathogens (Friedman et al. 1991). More recently, losses have been reported in seed oysters during summer months and have been attributed to "summer mortality;" however, recent research suggests differences between "summer mortality" of adult oysters and seed mortalities. Seed mortalities typically affect the smallest animals, are short in duration, and have been associated with warm water temperatures and an oyster herpesvirus (Renault et al.

\footnotetext{
*Corresponding author. E-mail: carolynf@u.washington.edu
}

1994a, 1994b, Renault et al. 2000, Friedman et al. 2005, Burge et al. 2006). To differentiate between adult summer mortality, losses of seed oyster during summer months are referred to as "summer seed mortality" or SSM.

SSM has been observed among Pacific oyster seed, Crassostrea gigas (Thunberg) in Tomales Bay, California (Friedman et al. 1997, Cherr \& Friedman 1998) and France (see review by Renault et al. 1994a, 1994b.) since 1993. Prior to this time average losses from plant to harvest $(\sim 18 \mathrm{mo})$ ranged from $15 \%$ to $35 \%$ (J. Finger, Hog Island Oyster Co., pers. comm.). In Tomales Bay, SSM events are typically short in duration (1-2 wk) and have been associated with elevated summer water temperatures and phytoplankton blooms (Cherr \& Friedman 1998). Initially, culture facilities located near the inner reaches of Tomales Bay, experienced delayed and/or lower losses than those in outer Tomales Bay locations where more productive phytoplankton communities and oceanic conditions have been documented (Cole 1989, Judah 2002). Growers reported that new seed and younger animals seemed to be more susceptible to these mortality events than older individuals. Survivors from 1993 plantings experienced lower losses than those planted oysters in 1994 (Cherr \& Friedman 1998). Only Pacific oysters in Tomales Bay appear to be affected by SSM; clams (Venerupis 
philippinarum), mussels (Mytilus galloprovincialis) and eastern (C. virginica), Olympia (Ostrea conchapilia $=O$. lurida), Kumamoto (C. sikamea), and flat oysters (Ostrea edulis) appear to be unaffected (J. Finger, pers. comm.).

In France, SSM occurs among C. gigas and O. edulis in the nursery and early grow-out in the field and has been associated with a herpesvirus infection (ostreid herpesvirus 1: OsHV-1) (Comps \& Cochennec 1993, Renault et al. 1994a, 1994b, Renault et al. 2000). OsHV induced losses of larvae also occur in several bivalve species in France: Pacific oysters, $C$. gigas (Nicolas et al. 1992), Manila clams, Venerupis (=Ruditapes) phillippinarum (Renault \& Arzul 2001, Renault et al. 2001), carpet clams, Ruditapes decussatus (Renault \& Arzul 2001, Arzul et al. 2001b), and French scallops, Pecten maximus (Arzul et al. 2001a); and in New Zealand: Pacific oysters, C. gigas, (Hine et al. 1992) and flat oysters Tiostrea chilensis (Hine et al. 1998). A similar virus was recently reported from Tomales Bay (Friedman et al. 2005) and is associated with SSM in Pacific oysters (Burge et al. 2006).

Multiple stressors such as elevated water temperature, pathogens (i.e., oyster herpesvirus), and/or phytoplankton blooms have been suggested as potential causes of SSM in Tomales Bay, CA. We examined the role of these stressors in SSM and hypothesize that SSM may be mitigated by the selection of mortality resistant stocks and outplant time. Therefore, the objective of this sentinel field study is to test the association of SSM with water temperature, phytoplankton blooms, and pathogens in Tomales Bay using three oyster stocks outplanted in the fall and the spring.

\section{MATERIALS AND METHODS}

Sentinel Monitoring Surveys: 2000-2001

\section{Oyster Stocks and Study Sites}

Monitoring surveys were conducted in California, USA at 3 sites: Inner Tomales Bay, Outer Tomales Bay, and Bodega Harbor; and at a single site in Washington state: Totten Inlet (Fig. 1). Oyster stocks were obtained from 2 suppliers: (1) Strait of Georgia, Washington state (WA-1) and (2) Yaquina Bay, Oregon (OR-1, predicted to be a high performing line based on previous survival and growth and OR-2, predicted to be a poor performing line) (C. S. Friedman unpubl. data), donated by the Molluscan Broodstock Program (C. Langdon, OR State University). Oyster condition was assessed in all stocks ( $n=20$ animals from each stock on each date) on October 10, 2000 and March 30, 2001 and no abnormalities were observed.

Pacific oyster stocks were planted in the fall of 2000 (October 27, 2000) in Tomales Bay (Inner and Outer Bay sites) and Bodega Harbor (California, USA). Cohorts of the animals planted in fall of 2000 were over-wintered at the source hatcheries and planted in the spring of 2001 (April 11, 2001) in Tomales Bay (Inner and Outer Bay sites), Bodega Harbor, and Totten Inlet. Three bags of oysters per stock were planted in $1 \mathrm{~cm}$ individual mesh Nytex bags $(61 \times 122 \mathrm{~cm})$ tied to metal racks approximately $30.5 \mathrm{~cm}$ above the sediment at the $+30.5 \mathrm{~cm}$ MLLW. One thousand oysters were planted per bag at all California sites; in Washington state 200 oysters were planted per bag. Variation in culture methods between California and Washington sites reflect differences in established culture methods in each area.

\section{Mortality, Growth, and Condition}

Seed mortality in replicate bags of oysters was monitored monthly after the outplant of the Spring cohort by counting the number of dead oysters (empty shells or gaping oysters) from a random sample of 100 oysters per bag. Monthly growth was monitored by measuring oyster height (length) to the nearest mm using vernier calipers except at Totten Inlet, where oysters were measured only at the beginning and end of the experiment. Animal condition was assessed using routine paraffin histology to detect the presence of morphological abnormalities and or pathogens. Oysters stocks planted in the Fall of 2000 were examined on April 11, $2001(n=90: 10$ animals collected from each stock from Bodega Harbor, Outer Tomales Bay, and Inner Tomales Bay on April 11). A subset of oysters from all stocks were examined during mortality episodes in Tomales Bay $(n=$ 27 survivors collected on June 5 and July 23). A standard cross section that included gills, mantle, gonad, and digestive gland was excised from each oyster and placed in Invertebrate Davidson solution (Shaw \& Battle 1957) for 24 h; a subset of samples collected were processed for routine paraffin histology. Deparaffinized, 5- $\mu \mathrm{m}$ tissue sections were stained with hematoxylin and eosin (Luna 1968) and viewed by light microscopy to assess the presence of parasites and or morphological changes.

\section{Environmental Parameters}

Temperature and phytoplankton abundance were monitored over the course of this survey. Temperature data were recorded at each site with continuous data loggers (YSI Inc.) and were binned into 1-h intervals for analysis. Phytoplankton samples were collected from Inner and Outer Tomales Bay sites and Bodega Harbor (May 1 to August 20, 2001). Weekly, nearsurface samples were collected from each site throughout the study period by lowering a bucket just below the surface. In addition twice-daily samples were collected in 2001 at Inner and Outer Tomales Bay sites using automated water samplers (Sigma 900 AS). At the Inner Bay site the sampler was located on a floating dock in water $0.6-30.5-\mathrm{m}$ deep depending on the tidal height) with the intake tube held at $15.2 \mathrm{~cm}$ below the surface. At the Outer Bay, a floating dock was not available so the sampler was located on a fixed platform with the intake set at $0.5 \mathrm{~m}$ above the mud surface and adjacent to oyster culture racks. A shortcoming of the fixed platform was that the intake was at times exposed to air at very low tides and thus some samples were missed. In addition, samples drawn when tides were lower than $0.6 \mathrm{~m}$ were often filled with organic detritus, making it difficult or impossible to identify and enumerate the phytoplankton cells. Comparison of cell counts from AS and bucket grabs at the same location and time revealed that the AS samples were similar in species composition and cell density $(P$ $=0.36$, T-test; Sokal \& Rohlf 1995). Thus data collected using both approaches are reported herein.

Phytoplankton samples were immediately preserved with $2 \%$ Lugol iodine solution and stored in a cool dark room at the Bodega Marine Laboratory until they were analyzed using the Utermohl technique (Utermohl 1958). Typically 50-mL subsamples were examined by quantifying phytoplankton to the species level or higher taxonomic affiliation (e.g., genus) according to Thomas (1997). Ten fields (or more for up to 200 cells) of view at $200 \times$ magnification were enumerated for each sample. Only cells $>7-\mu \mathrm{m}$ diameter were counted. 
$47.2 \mathrm{~N}$

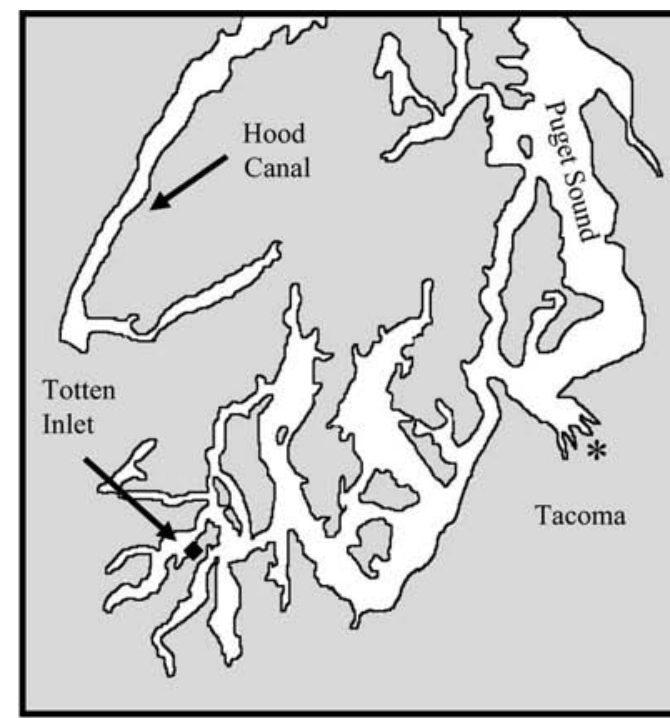

$122.4 \mathrm{~W}$

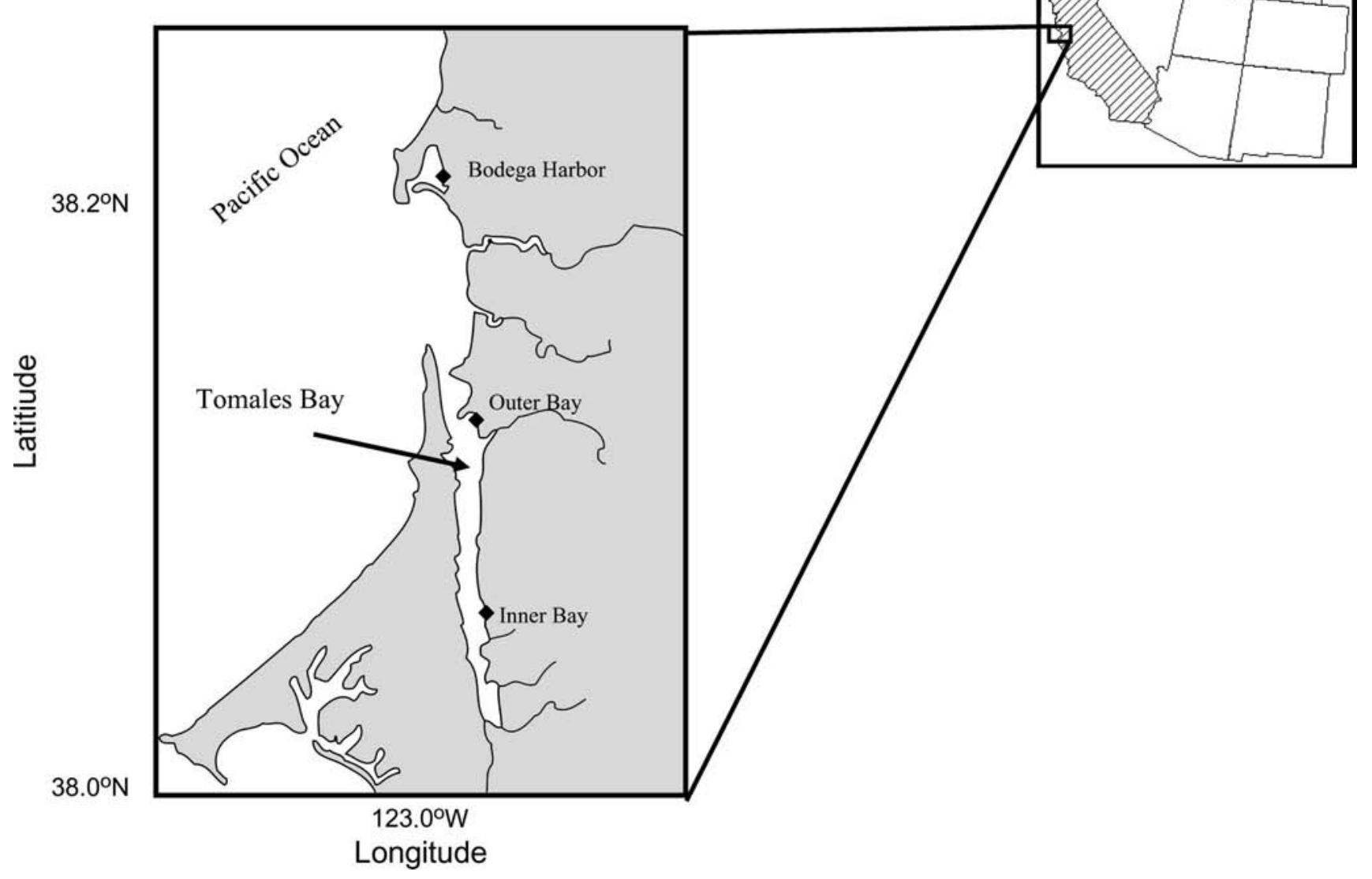

Figure 1. Map of field planting locations in California: Tomales Bay (Inner and Outer Bay sites), Bodega Harbor and Washington: Totten Inlet. Bodega Harbor and Totten Inlet are control sites where seed oyster mortality has not been documented.

\section{Data Analysis}

Differences among cumulative mortality (all sites) and final shell height (Bodega Harbor and Tomales Bay sites in 2001) were analyzed among stocks by a one-way analysis of variance and differences identified using a Tukey Test (Zar 1999). Finite mortality rates were calculated as the number of oysters that died from one mortality survey to the next and as total inferred mortalities divided by the number of oysters originally outplanted. Mortality data were arcsine transformed, which establishes the variance for percentage data (Zar 1999). Pearson moment correlation ( $r$ ) was used to test for a linear relationship between growth rate and mortality (Sigma Stat 2.02). 
Potential stressors, including daily mean temperature, temperature exposure, binned temperature (mean, maximum, and minimum), and phytoplankton assemblages were compared among sites or to mortality as appropriate. Daily mean temperatures at each site were found to be serially auto-correlated, with the same first-order serial correlation. To compare mean temperature at each site (April 25 to August 21, 2001) six Z-tests were calculated to compare the four means using an adjustment factor for first-order serial correlation (Ramsey \& Schafer 2002) corrected with a Bonferroni $P$ value. Hours of temperature over $16^{\circ} \mathrm{C}, 18^{\circ} \mathrm{C}, 20^{\circ} \mathrm{C}, 22^{\circ} \mathrm{C}$, and $24^{\circ} \mathrm{C}$ for each two-week period were quantified from January to August in 2001, and data collected between April 25, 2001 to August 21, 2001 were compared between sites using a one-way ANOVA. Temperature mean, maxima, and minima were binned between mortality surveys, and the Spearman Rank Correlation (SRC) was used to test if a linear relationship existed between binned temperature and mortality (SPSS 11.5). Similarly, the SRC was used to test for a linear relationship between mortality and binned phytoplankton groupings defined as total mean cells and mean densities of dinoflagellates (including the potentially toxic
Akashiwo sanguinea), diatoms and flagellates at Inner and Outer Tomales Bay sites and Bodega Harbor.

\section{RESULTS}

\section{Sentinel Field Surveys: 2000 and 2001}

\section{Mortality, Growth, and Condition}

Cumulative mortality was significantly different among sites $(P<0.0001$, Table 1$)$ and stocks $(P<0.0001$, Fig. 2$)$. In two of the three stocks examined (WA-1 and OR-2), mortality was significantly lower in the Fall outplants than the Spring outplants $(P<0.0001)$. Mortality was higher at the Inner Bay site $(40 \%$ to $100 \%)$ than at the Outer Bay site $(0-25 \%)$ or Bodega Harbor and Totten Inlet sites where losses were minimal $(0 \%$ to $2 \%$ ). A stock by site interaction was detected because of the sitespecific mortality affecting stocks grown at the Inner Bay site. At the Inner Bay site, mortality was highest between May 23 and June 8; for the reminder of the experiment, mortality was low for all groups except for the Fall outplant of OR-2. At the Outer Bay site, instantaneous mortality was less than $6 \%$ per

TABLE 1.

Instantaneous ${ }^{1}$ and cumulative (cum.) ${ }^{2}$ mortalities of three stocks ${ }^{3}$ of Pacific oysters in 2000-2001.

\begin{tabular}{|c|c|c|c|c|c|c|c|}
\hline \multirow[b]{2}{*}{ Site $^{4}$} & \multirow[b]{2}{*}{ Date } & \multicolumn{6}{|c|}{ Percent Mortality (\%) } \\
\hline & & WA-1 $(F)^{5}$ & WA-1(S) ${ }^{5}$ & OR-1(F) ${ }^{5}$ & OR-1(S) ${ }^{5}$ & OR-2(F) & OR-2(S) ${ }^{5}$ \\
\hline \multirow[t]{7}{*}{ IB } & $5 / 23$ & 0 & 0 & 0 & 0 & 0 & 0 \\
\hline & $6 / 8^{6}$ & $34.6 \pm 10.2$ & $66.81 \pm 11.64$ & $36.80 \pm 13.46$ & $60.69 \pm 8.00$ & $32.84 \pm 28.55$ & 100 \\
\hline & $6 / 26$ & $6.67 \pm 5.01$ & $23.33 \pm 11.84$ & $13.00 \pm 2.00$ & $25.67 \pm 15.14$ & $18.00 \pm 11.27$ & 0 \\
\hline & $7 / 24$ & $1.50 \pm 0.62$ & $2.50 \pm 4.42$ & $2.00 \pm 3.33$ & $4.67 \pm 4.73$ & $39.98 \pm 40.55$ & 0 \\
\hline & $8 / 21$ & $0.20 \pm 0.20$ & $0.67 \pm 1.21$ & $3.00 \pm 1.00$ & 0 & 0 & 0 \\
\hline & $9 / 17$ & $0.33 \pm 0.21$ & $1.17 \pm 0.98$ & 0 & $6.67 \pm 11.55$ & $0.33 \pm 0.33$ & 0 \\
\hline & Cum. & $40.03 \pm 11.30$ & $76.66 \pm 6.42$ & $47.45 \pm 10.87$ & $74.85 \pm 1.75$ & $56.34 \pm 15.45$ & 100 \\
\hline \multirow[t]{7}{*}{ OB } & $5 / 24$ & 0 & 0 & 0 & 0 & 0 & 0 \\
\hline & $6 / 25$ & 0 & 0 & 0 & 0 & 0 & 0 \\
\hline & $7 / 23$ & $0.50 \pm 1.22$ & $0.80 \pm 2.00$ & 0 & 0 & $0.01 \pm 0.01$ & 0 \\
\hline & $8 / 6$ & 0 & $5.30 \pm 3.35$ & 0 & 0 & $0.01 \pm 0.01$ & $12.50 \pm 17.7$ \\
\hline & $8 / 22$ & 0 & $5.50 \pm 6.97$ & 0 & 0 & 0 & $2.50 \pm 3.50$ \\
\hline & $9 / 18$ & 0 & $0.10 \pm 0.40$ & 0 & 0 & 0 & $9.65 \pm 12.23$ \\
\hline & Cum. & $0.50 \pm 1.22$ & $11.34 \pm 10.50$ & 0 & 0 & $0.01 \pm 0.01$ & $24.88 \pm 6.47$ \\
\hline \multirow[t]{5}{*}{$\mathrm{BH}$} & $5 / 29$ & 0 & 0 & 0 & 0 & 0 & 0 \\
\hline & $6 / 28$ & 0 & 0 & 0 & 0 & 0 & $0.01 \pm 0.01$ \\
\hline & $7 / 25$ & 0 & 0 & 0 & 0 & 0 & 0 \\
\hline & $9 / 18$ & 0 & 0 & 0 & 0 & 0 & 0 \\
\hline & Cum. & 0 & 0 & 0 & 0 & 0 & $0.01 \pm 0.01$ \\
\hline \multirow[t]{6}{*}{ TI } & $7 / 31$ & $\mathrm{NA}^{7}$ & $\mathrm{NA}^{7}$ & $\mathrm{NA}^{7}$ & 0 & $\mathrm{NA}^{7}$ & 0 \\
\hline & $8 / 15$ & $\mathrm{NA}^{7}$ & $\mathrm{NA}^{7}$ & $\mathrm{NA}^{7}$ & $0.30 \pm 0.45$ & $\mathrm{NA}^{7}$ & $0.50 \pm 0.58$ \\
\hline & $8 / 30$ & $\mathrm{NA}^{7}$ & $\mathrm{NA}^{7}$ & $\mathrm{NA}^{7}$ & $0.20 \pm 0.45$ & $\mathrm{NA}^{7}$ & $0.34 \pm 0.58$ \\
\hline & $9 / 13$ & $\mathrm{NA}^{7}$ & $\mathrm{NA}^{7}$ & $\mathrm{NA}^{7}$ & 0 & $\mathrm{NA}^{7}$ & $0.17 \pm 0.29$ \\
\hline & 10.20 & $\mathrm{NA}^{7}$ & $\mathrm{NA}^{7}$ & $\mathrm{NA}^{7}$ & 0 & $\mathrm{NA}^{7}$ & $1.18 \pm 1.27$ \\
\hline & Cum. & $\mathrm{NA}^{7}$ & $\mathrm{NA}^{7}$ & $\mathrm{NA}^{7}$ & $0.50 \pm 0.71$ & $\mathrm{NA}^{7}$ & $2.33 \pm 2.02$ \\
\hline
\end{tabular}

\footnotetext{
${ }^{1}$ At each sample date, mortality is listed as instantaneous (+/- standard deviation) or the proportion of animals dead during this sample period.

${ }^{2}$ Cumulative mortality is the number of oysters that died through the whole experiment divided by the \# of oysters per bag.

${ }^{3}$ Oysters stocks are as follows: WA-1, a hatchery stock from Georgia Strait, WA State; OR-1, a high performing family line from Yaquina Bay; Oregon; OR-2, a low performing family line from Yaquina Bay, OR.

${ }^{4}$ Sites are abbreviated as follows: Inner Tomales Bay, IB; Outer Tomales Bay, OB; Bodega Harbor, BH, and Totten Inlet, TI.

${ }^{5} \mathrm{~F}$ denotes fall and $\mathrm{S}$ denotes spring outplants.

${ }^{6}$ IB was monitored on both $6 / 5 / 2001$ and $6 / 8 / 2001$ and the column labeled $6 / 8 / 2001$ is the average mortality for the two days.

${ }^{7}$ Only OR-1 and OR-2 were outplanted in the Spring in Totten Inlet.
} 
Low Mortality WA-1 (F) OR-1 $(F)$ OR-2 (F) OR-1 $(\mathrm{S})$ WA-1 (S)

High Mortality OR-2 (S)

Figure 2. Statistical differences $(P<0.0001)$ in cumulative mortality (arcsine transformed) among the three stocks of Pacific oysters grown in Tomales Bay, CA in 2000-2001.

sampling except for the Spring outplant of OR-2, which experienced losses ranging from $9.7 \%$ to $12.5 \%$.

Oyster shell heights are summarized in Table 2. Oysters planted in the Spring were significantly larger than those planted in the Fall at planting time $(P<0.0001)$. However, oysters that were over-wintered in the bay (Fall outplants) were significantly larger than their Spring cohorts when the first morphometric measurement was taken in late May $(P<0.0001)$. Oysters grown at the Inner Bay site grew significantly larger than oysters grown in the Outer Bay or Bodega Harbor sites $(P<0.0001)$. Outer Bay oysters were also larger than those grown in Bodega Harbor $(P<0.0001)$. Final shell heights differed among stocks and between outplant time at all sites $(P<$ 0.0001 , Fig. 3). Growth rate and cumulative mortality were significantly correlated at the Inner Bay site where losses were highest $(P<0.05, \mathrm{r}=0.916)$. Growth rate and cumulative mortality were not significantly correlated at the Outer Bay $(P>0.05)$ or Bodega Harbor $(P>0.05)$ sites.

Animals were examined using light microscopic examination of standard hemotoxylin and eosin tissues. Normal tissue architecture was noted in oysters examined before outplant, premortality, and oysters grown at the Outer Bay site during and after mortality outbreaks (July 23). Oysters collected during the
5 of June 2001 mortality event ( $n=27$ survivors) at the Inner Bay site revealed morphological changes in the digestive gland and connective tissues. Microscopic changes in tissue architecture were observed in 13 of 27 surviving oysters and included diffuse to multifocal peritubular hemocyte infiltration, diapedesis and dilation of digestive tubules some of which contained cellular debris (Fig. 4). Nuclear changes, including hypertrophy, chromatin margination, and diffuse central eosinophilia were seen in several cells within connective tissue adjacent to digestive tubules (Fig. 4D).

\section{Environmental Parameters}

Differences in mean daily temperature exposure were detected among sites in 2001 (Fig. 5, $P<0.05$ ). Mean temperature exposure was the same among sites in Tomales Bay $(P<$ $0.05)$ and was similar between the Outer Bay site and Totten Inlet $(P>0.05)$ sites. Inner Bay oysters were exposed to higher mean temperatures than oysters reared at Totten Inlet $(P<0.05)$. Oysters grown at Bodega Harbor experienced lower mean temperatures than oysters grown at both Tomales Bay sites (Inner Bay: $P<0.0001$, Outer Bay: $P<0.01$ ) and Totten Inlet ( $P=0.00957$ uncorrected, $P=0.0574$ Bonferroni corrected). The marginal $P$ value for the comparison of mean temperatures between Bodega Harbor and Totten Inlet may be explained by the conservative nature of the Bonferroni method, and the highly significant nature of the original $P$ value of 0.00957 , indicating that oysters grown in Bodega Harbor experienced lower mean water temperatures than those grown at Totten Inlet.

Significant trends were observed when oyster losses were examined in relation to temperatures. Mortality surveys

TABLE 2.

Shell height (mean \pm SD) of three stocks ${ }^{1}$ of Pacific oysters in 2000-2001.

\begin{tabular}{|c|c|c|c|c|c|c|c|}
\hline \multirow[b]{2}{*}{ Site $^{2}$} & \multirow[b]{2}{*}{ Date } & \multicolumn{6}{|c|}{ Oyster Height } \\
\hline & & WA-1 $(\mathbf{F})^{3}$ & WA-1(S) ${ }^{3}$ & OR-1(F) ${ }^{3}$ & OR-1(S) ${ }^{3}$ & OR-2(F) ${ }^{3}$ & OR-2(S) ${ }^{3}$ \\
\hline \multirow{5}{*}{ IB } & Pre-plant ${ }^{4}$ & $9.5 \pm 1.9$ & $10.4 \pm 1.8$ & $4.7 \pm 1.7$ & $6.0 \pm 2.6$ & $6.4 \pm 0.7$ & $9.5 \pm 1.2$ \\
\hline & $5 / 24$ & $58.0 \pm 14.2$ & $18.8 \pm 5.4$ & $45.6 \pm 8.6$ & $15.7 \pm 4.3$ & $45.5 \pm 20.4$ & $19.8 \pm 6.3$ \\
\hline & $7 / 24$ & $59.2 \pm 15.8$ & $45.8 \pm 10.4$ & $66.6 \pm 12.6$ & $41.7 \pm 7.8$ & $64.3 \pm 13.1$ & $\mathrm{NA}^{5}$ \\
\hline & $9 / 17$ & $75.0 \pm 15.4$ & $64.4 \pm$ & 12.7 & $56.7 \pm 10.6$ & $76.3 \pm 12.9$ & $\mathrm{NA}^{5}$ \\
\hline & Total change $^{6}$ & 65.6 & 54 & 70.6 & 50.7 & 69.9 & $\mathrm{NA}^{5}$ \\
\hline \multirow[t]{5}{*}{ OB } & Pre-plant ${ }^{4}$ & $9.5 \pm 1.9$ & $10.4 \pm 1.8$ & $4.7 \pm 1.7$ & $6.0 \pm 2.6$ & $6.4 \pm 0.7$ & $14.4 \pm 8.0$ \\
\hline & $5 / 25$ & $41.1 \pm 14.5$ & $15.1 \pm 4.4$ & $41.4 \pm 9.9$ & $11.3 \pm 3.9$ & $37.8 \pm 18.9$ & $14.4 \pm 8.0$ \\
\hline & $7 / 23$ & $64.8 \pm 13.7$ & $41.3 \pm 11.9$ & $53.6 \pm 12.1$ & $29.6 \pm 13.6$ & $58.5 \pm 12.5$ & $36.9 \pm 9.4$ \\
\hline & $9 / 18$ & $80.7 \pm 17.1$ & $54.4 \pm 11.3$ & $67.7 \pm 14.7$ & $50.4 \pm 14.6$ & $70.8 \pm 14.5$ & $52.2 \pm 14.2$ \\
\hline & Total change ${ }^{6}$ & 71.3 & 43.9 & 63 & 44.4 & 64.4 & 42.6 \\
\hline \multirow[t]{4}{*}{$\mathrm{BH}$} & Pre-plant ${ }^{4}$ & $9.5 \pm 1.9$ & $10.4 \pm 1.8$ & $4.7 \pm 1.7$ & $6.0 \pm 2.6$ & $6.4 \pm 0.7$ & $9.5 \pm 1.2$ \\
\hline & $5 / 29$ & $40.7 \pm 10.6$ & $15 \pm 2.7$ & $22.1 \pm 8.1$ & $8.3 \pm 3.7$ & $29.6 \pm 8.6$ & $14.1 \pm 5.0$ \\
\hline & $9 / 17$ & $54.3 \pm 16.6$ & $36.2 \pm 12.2$ & $56.9 \pm 16.0$ & $26.5 \pm 10.9$ & $54.7 \pm 11.3$ & $38.2 \pm 14.7$ \\
\hline & Total change ${ }^{6}$ & 44.9 & 25.7 & 52.2 & 20.6 & 48.3 & 28.6 \\
\hline \multirow[t]{3}{*}{$\mathrm{TI}$} & Pre-plant ${ }^{4}$ & NA & NA & NA & $7.3 \pm 2.0$ & NA & $11.5 \pm 4.1$ \\
\hline & $10 / 20$ & NA & NA & NA & $60.8 \pm 7.8$ & NA & $47.2 \pm 8.3$ \\
\hline & Total change ${ }^{6}$ & NA & NA & NA & 53.6 & NA & 35.7 \\
\hline
\end{tabular}

${ }^{1}$ Oysters stocks are as follows: WA-1, a hatchery stock from Georgia Strait, WA State; OR-1, a high performing family line from Yaquina Bay, OR; OR-2, a low performing family line from Yaquina Bay, OR.

${ }^{2}$ Sites are abbreviated as follows: Inner Tomales Bay, IB; Outer Tomales Bay, OB; Bodega Harbor, BH; and Totten Inlet, TI.

${ }^{3} \mathrm{~F}$ denotes fall and $\mathrm{S}$ denotes spring outplants.

${ }^{4}$ Oysters planted in fall were measured on 11/27/2000 and oysters planted in the spring were measured on 4/11/2001.

${ }^{5} 100 \%$ mortality was observed in the OR-2 on $6 / 8 / 2001$.

${ }^{6}$ Total height change is expressed as the average final shell height minus the average initial shell height. 
Large oysters

A)

OR-2 (F) OR-1 (F) WA-1 (F) WA-1 (S) OR-1(S)

B)

WA-1 (F) OR-2 (F) OR-1 (F) WA-1 (S) OR-2 (S) OR-1 (S)

C)

OR-1 (F) OR-2 (F) WA-1 (F) OR-1 (S) WA-1 (S) OR-1 (S)

Figure 3. Statistical differences $(P<0.0001)$ among final shell height in the three stocks of Pacific oysters grown at (a) Inner Tomales Bay, (b) Outer Tomales Bay, and (c) Bodega Harbor in 2000-2001.

conducted on June 5 and 8 revealed high losses in all groups, particularly in Spring outplants at the Inner Bay site. In fact, maximum temperatures significantly correlated with mortality at the Inner Bay site only $(\mathrm{r}=0.949, P<0.05)$. The first temperature maximum over $24^{\circ} \mathrm{C}$ occurred 15 days before losses of up to $50 \%$ at the Inner Bay site (Fig. 6). Immediately prior to oyster losses, during the period of May 19 to June 8, all sites had a temperature maximum exceeding $24^{\circ} \mathrm{C}$ (Fig. 5), however oysters grown at the Inner Bay site experienced several temperature maximums of $>24^{\circ} \mathrm{C}$ prior to losses (Fig. 6). No correlation was detected between high temperatures and mortality at the Outer Bay, Bodega Harbor, or Totten Inlet sites $(P>0.05)$. Mortality events were not significantly correlated with the average $(P>0.05)$, minimum $(P>0.05)$, or temperature ranges
$(P>0.05)$ at any of the three sites. On a monthly basis, the Inner Bay experienced a greater number of hours of exposure than all other sites to temperatures in excess of $16^{\circ} \mathrm{C}, 18^{\circ} \mathrm{C}, 20^{\circ} \mathrm{C}$, and $22^{\circ} \mathrm{C}$, and Totten Inlet experienced the most hours greater than $24^{\circ} \mathrm{C}$ (Fig. 7). When comparing duration of temperatures in excess of $16^{\circ} \mathrm{C}, 18^{\circ} \mathrm{C}, 20^{\circ} \mathrm{C}, 22^{\circ} \mathrm{C}$, and $24^{\circ} \mathrm{C}$ between sites, only temperatures in excess of $18^{\circ} \mathrm{C}(P<0.05), 20^{\circ} \mathrm{C}(P<0.05)$, and $22^{\circ} \mathrm{C}(P<0.05)$ presented differences among sites (Fig. 8).

Diatoms dominated phytoplankton assemblages at the Tomales Bay sites and at the Bodega Harbor site in July (Fig. 9). In May, June, and August dinoflagellates and other flagellates dominated the composition of samples at the Bodega Harbor site. No correlation between phytoplankton groupings (total cells, mean dinoflagellates (including the potentially toxic Akashiwo sanguinea), mean diatoms, and mean flagellates) and mortality ( $P>0.05$ for all listed groupings) was found at either Tomales Bay site, or Bodega Harbor.

\section{DISCUSSION}

In our 2000-2001 field study, a commercially available oyster stock, WA-1, performed equally or better than other stocks including those from specific family lines used in this study (OR-1 and OR-2) indicating that selection of oyster stocks (or family lines) may help mitigate losses of Pacific oyster seed caused by SSM. Differences in oyster genetics (oyster stocks or family lines) have been shown to influence seed oyster survival (Degremont et al. 2005), and survival can have a strong genetic basis in areas of seed mortality (Degremont et al. 2007).
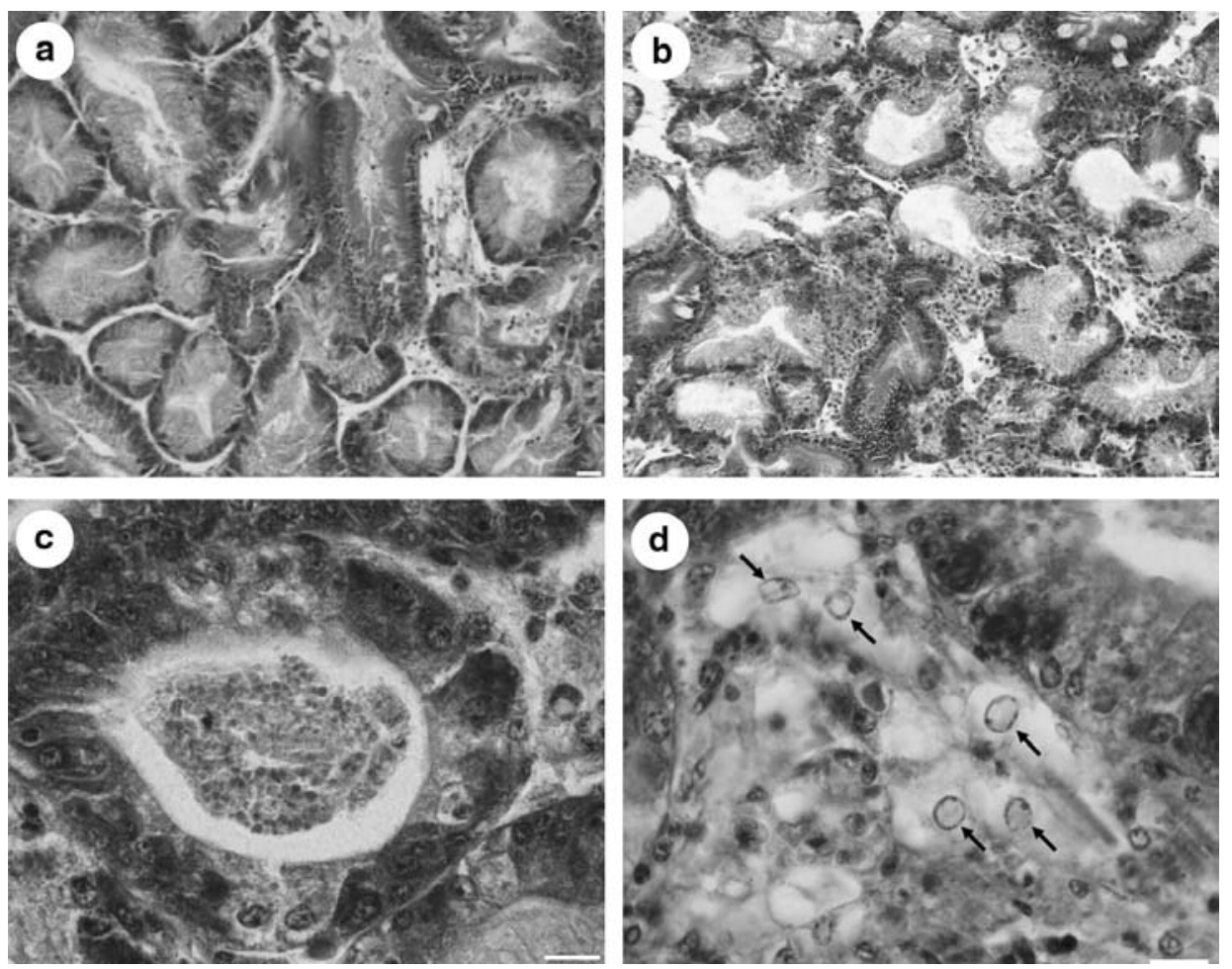

Figure 4. Normal and abnormal tissue and cellular architecture of oysters collected at the Inner Bay site during the June 5, 2001 mortality event (a) Normal digestive gland architecture, Scale bar $=20 \mu \mathrm{m}$, (b) Hemocyte infiltration (inflammation) surrounding dilated digestive tubules, Scale bar $=$ $20 \mu \mathrm{m}$, (c) Dilated digestive tubule containing cellular debris, scale bar $=10 \mu \mathrm{m}$, and (d) Enlarged cell nuclei with chromatin margination suggestive of herpesvirus infection (arrows), scale bar $=10 \mu \mathrm{m}$. Hematoxylin and eosin. 

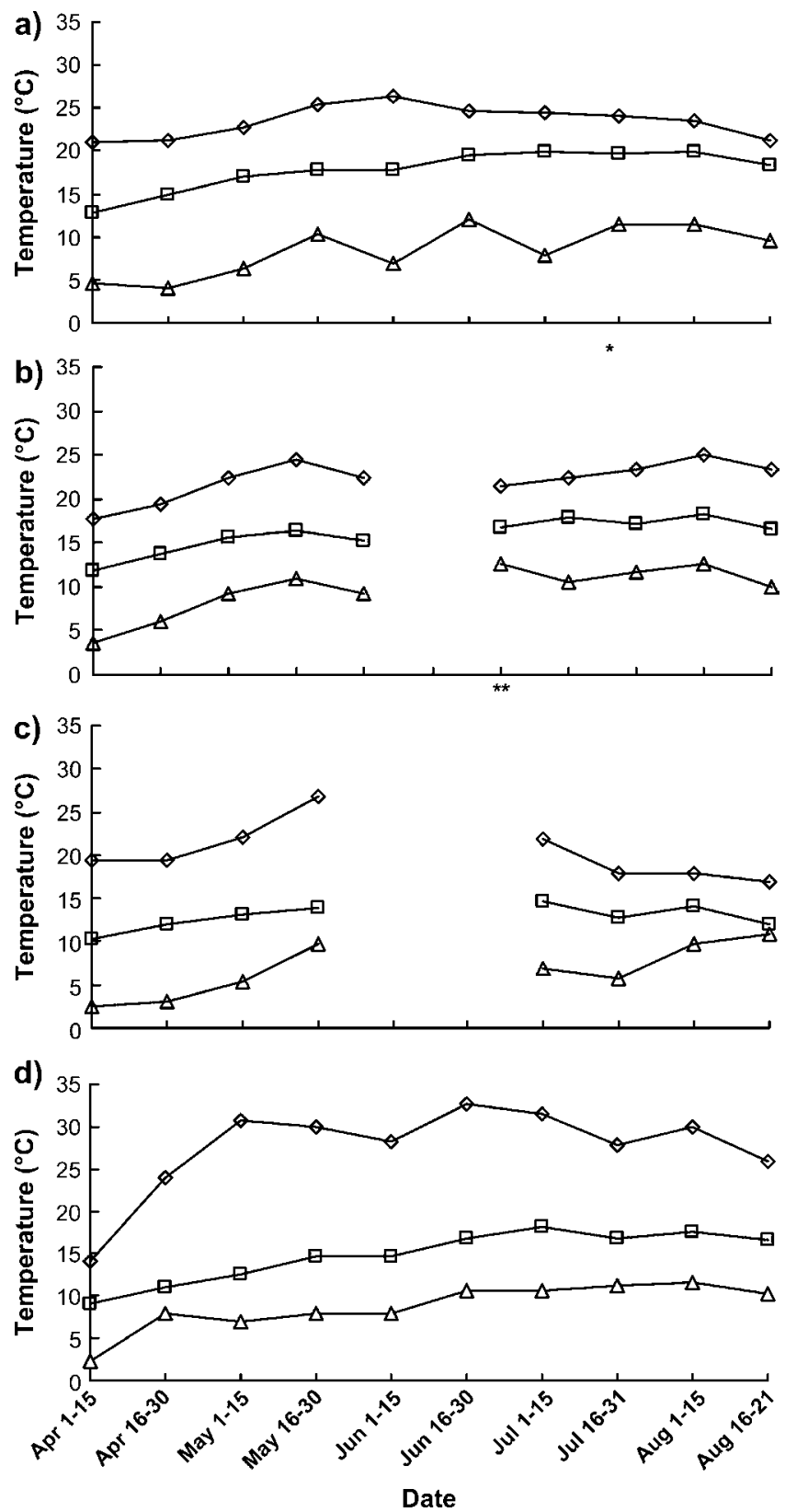

Figure 5. Bimonthly temperature maxima $(\diamond)$, means $(\square)$, and minima $(\Delta)$ at (a) Inner Tomales Bay, (b) Outer Tomales Bay, (c) Bodega Harbor, and (d) Totten Inlet from April 1 to August 21, 2001. *July 24-31. $* *$ June 25-30.

Furthermore, the use-selected lines may enhance disease resistance in seed oysters (Calvo et al. 2003). Outplant time helped mitigate losses from SSM; our study demonstrated for the first time that oyster cohorts planted in the Fall outperformed cohorts planted the following Spring, the standard industry plant time. Thus losses may be mitigated or dampened by careful selection of planting time. Fall cohorts may have outperformed those planted in the Spring because (1) Fall cohorts had a longer time to acclimate to Tomales Bay conditions or (2) Fall cohorts were of a much larger size than Spring cohorts when mortality occurred. In support of the second lines of reasoning, five stocks of oysters were outplanted

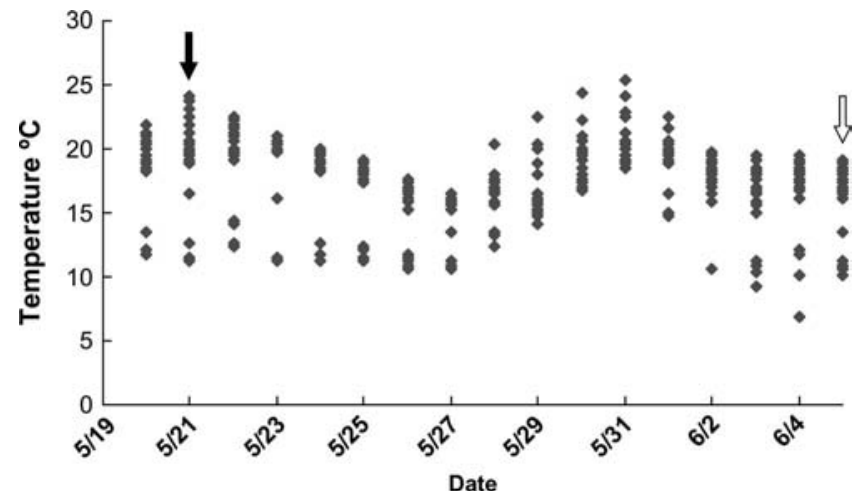

Figure 6. Daily Inner Tomales Bay temperatures between May 20, 2001 and June 5, 2001. On May 21, 2001 temperatures exceeded $24^{\circ} \mathrm{C}$ for the first time (dark arrow). On June 5, 2001, the first mortality of the summer was observed (light arrow).

in Tomales Bay in Spring only, and higher survival was documented in stocks with larger individuals (Burge et al. 2006).

No correlation between phytoplankton blooms and mortality was observed in the 2000-2001 experiment reported herein. Phytoplankton blooms have been associated with SSM in Tomales Bay (Cherr \& Friedman 1998) and were also related to mortalities in adult oysters from a 1998 field study of Cheney et al. (2000). These data suggest that phytoplankton blooms are not consistently related to oyster losses in Tomales Bay and that other stressors such as elevated water temperature or a pathogen (an oyster herpesvirus) are involved.

Temperature exposure and maxima $\left(\sim 25^{\circ} \mathrm{C}\right)$ have been repeatedly associated with SSM in Tomales Bay (Cherr \& Friedman 1998, Burge et al. 2006) and were associated with losses in this study. Burge et al. (2006) examined the relationship between temperature and mortalities at the Inner Tomales Bay site considering three years $(2001,2002$, and 2003), and the only temperature consistently related to mortalities were total exposure and degree hours per day in excess of $24^{\circ} \mathrm{C}$ and $25^{\circ} \mathrm{C}$. These yearly maximum temperatures are not considered to be extreme for Pacific oyster survival (Cheney et al. 2000). In fact, oysters can exhibit phenotypic plasticity where chronic exposure to sublethal temperature stress can protect oysters even at otherwise lethal temperatures of $41^{\circ} \mathrm{C}$ to $46^{\circ} \mathrm{C}$ (Clegg et al. 1998 , Hamdoun et al. 2003) far in excess of those observed in this study. In addition, immune function (hemocyte mortality, phagocytosis, esterase, and aminopeptidase activities) in adult Pacific oysters appears to be unaffected at $25^{\circ} \mathrm{C}$ based on in vivo and in vitro exposure of hemocytes for 2 and 4 h, respectively (Gagnaire et al. 2006), suggesting that seed oyster immunity should not be compromised at $25^{\circ} \mathrm{C}$. Therefore, temperature is unlikely to be the lone stressor involved in SSM in Tomales Bay, CA.

Histological examination of oysters sampled during the Inner Bay mortality event suggests herpesvirus infection based on nuclear changes, including cells with hypertrophy and chromatin margination. Histological micrographs similar to those provided herein have been documented in herpesvirus infected seed oysters in France (Renault et al. 1995) and Tomales Bay (Burge et al. 2006). In the present study, extreme losses were documented when temperatures exceeded $24^{\circ} \mathrm{C}$ to $25^{\circ} \mathrm{C}$ levels, which are believed to lead to viral expression and mortality in OsHV-1 infected larvae (Le Deuff et al. 1996) and 
a)

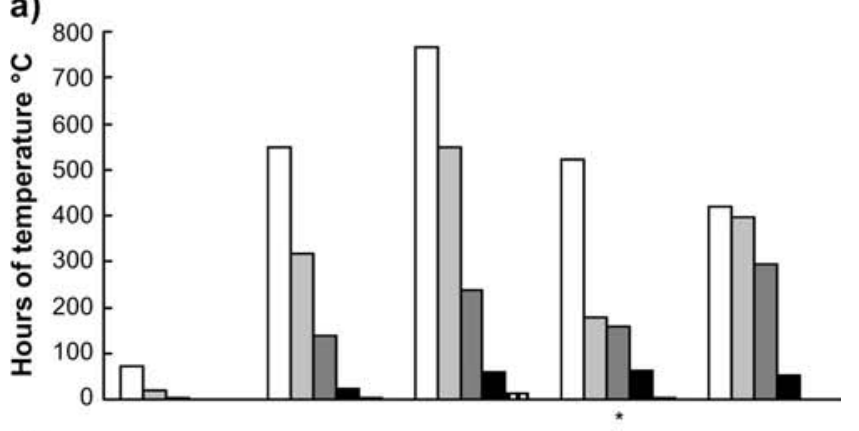

b)

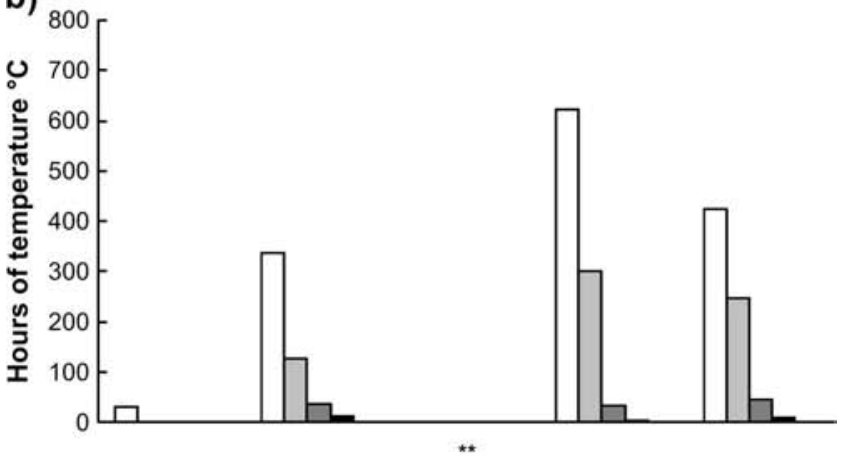

c)

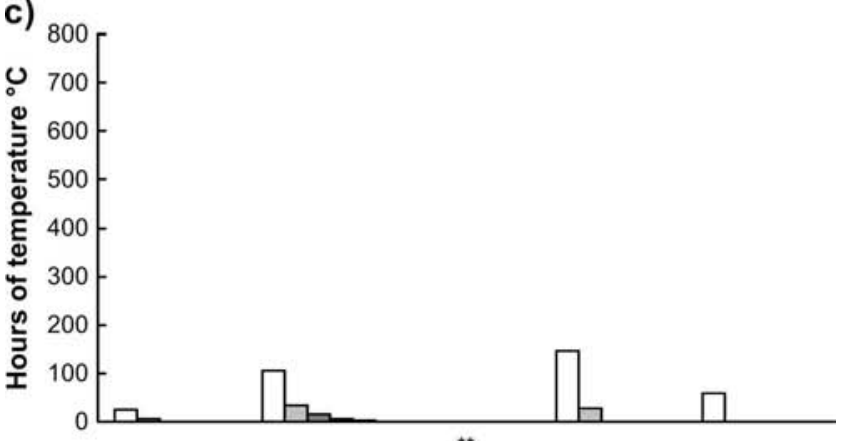

d)

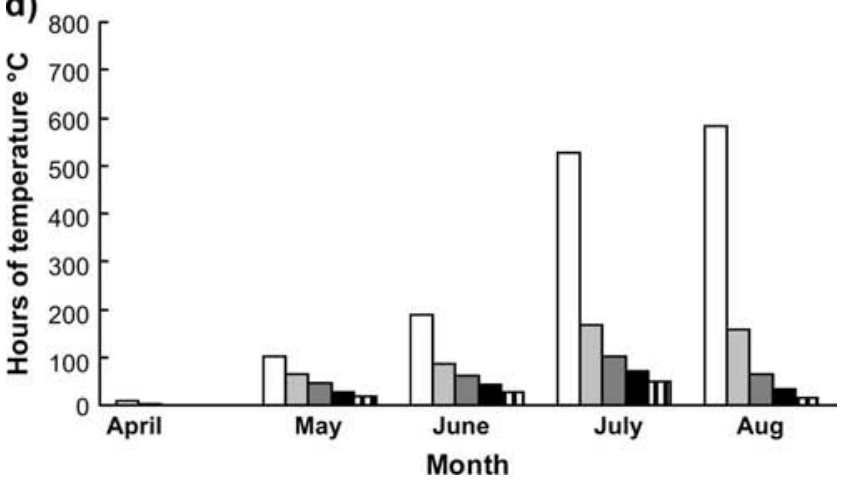

Figure 7. Hours exposed to temperatures in excess of $16^{\circ} \mathrm{C}$ (white bar), $18^{\circ} \mathrm{C}$ (light gray bar), $20^{\circ} \mathrm{C}$ (gray bar), $22^{\circ} \mathrm{C}$ (black bar), and $24^{\circ} \mathrm{C}$ (striped bar) at the (a) Inner Tomales Bay, (b) Outer Tomales Bay, (c) Bodega Harbor, and (d) Totten Inlet from April 1 to August 21, 2001. *Data from July 10 through 27 are not available for the Inner Bay site. **June data are not available for Bodega Harbor and the Outer Bay sites. a) $16{ }^{\circ} \mathrm{C}$

Low exposure

Bodega Harbor Totten Inlet Outer Bay High exposure

b) $18^{\circ} \mathrm{C}$

Low exposure High exposure

Bodega Harbor Totten Inlet_Outer Bay_Inner Bay

c) $20^{\circ} \mathrm{C}$

Low exposure

Bodega Harbor Outer Bay Totten Inlet

High exposure

d) $22{ }^{\circ} \mathrm{C}$

Low exposure

Bodega Harbor Outer Bay Totten Inlet Inner Bay

Figure 8. Statistical differences $(P<0.05)$ in temperature exposure at temperatures greater than (a) $16^{\circ} \mathrm{C}$, (b) $18^{\circ} \mathrm{C}$, (c) $20^{\circ} \mathrm{C}$, and (d) $22^{\circ} \mathrm{C}$ experienced by Pacific oysters grown at Bodega Harbor, Totten Inlet, Outer Tomales Bay, and Inner Tomales Bay in 2001.

seed (Burge et al. 2006). Therefore, correlation of high temperature with SSM is likely caused by expression of OsHV infections (Burge et al. 2006).

Not all oysters collected during the Inner Bay mortality event exhibited histological changes, and nuclear changes suggestive of herpesvirus infection were rare. At the Inner Bay site, 13 of 27 oysters collected during mortality events exhibited typical changes in tissue and cellular architecture including: dilated digestive gland tubules, pertibular to multifocal hemocyte infiltration, and cells undergoing diapedesis across digestive gland tubules. Although nuclear changes characteristic of herpesvirus infection have been reliably documented in larval oysters (Hine et al. 1992, Renault et al. 1994a); observations of nuclear changes in seed infected by oyster herpesviruses are rare (Friedman et al. 2005, Burge et al. 2006). Non-moribun oysters collected postmortality may be survivors of OsHV infections,

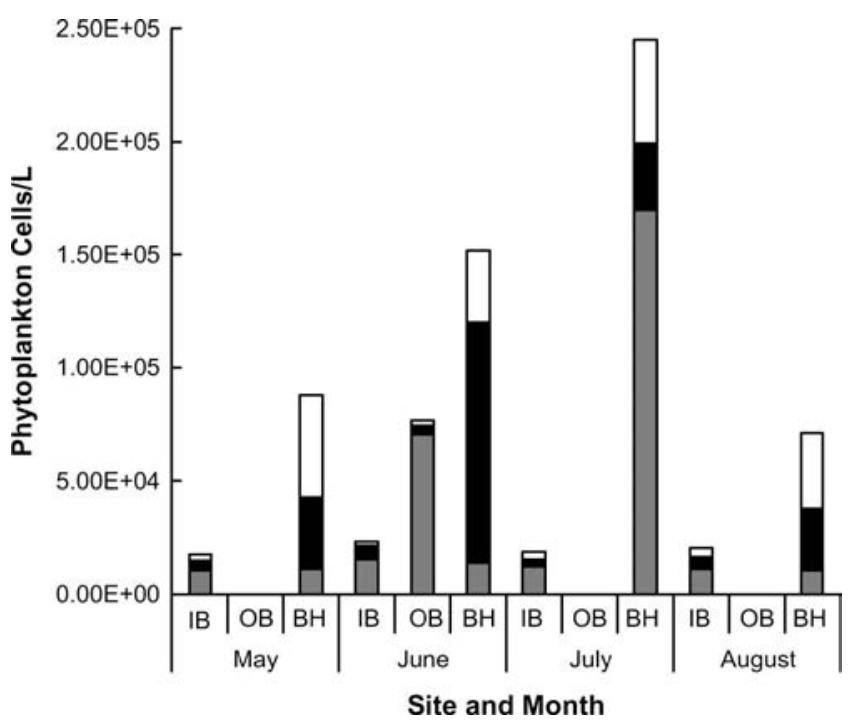

Figure 9. Tomales Bay phytoplankton seasonal trends including diatoms (gray bars), dinoflagellates (black bars), and other flagellates (white bars). Note that although losses began at the Inner Bay site in early June 2001, no phytoplankton bloom was recorded. 
and may not have active, productive herpesvirus infections; instead they may have low level productive yet asymptomatic, or latent herpesvirus infections where visible damage to host cells may not occur (Barbosa-Solomieu et al. 2004) as observed in many oyster samples collected after the early June mortality event in the present study. Thus oysters with inactive infections (survivors) may not exhibit histological changes suggestive of herpesviruses. Therefore, the use of multiple diagnostic tests (i.e., PCR, in situ hybridization, and histology) are important in diagnosing "unknown" oyster seed mortalities, particularly if OsHV is a possible cause (Lipart \& Renault 2002). Additionally, OsHV-1 detection using the PCR is significantly improved if oyster samples contain moribund oysters or are collected less than one week from the beginning of the mortality (Celine Garcia, IFREMER, pers. comm.).

In conclusion, mortalities and elevated temperatures have been associated with oyster losses since 1993 and this association was clearly demonstrated between 2001 to 2003 in Tomales Bay. In the later three years, oyster herpesviral infection has been suspected as playing a role in SSM of oysters grown in Tomales Bay based on histology (2001, the present study) and molecular data from 2002 (Friedman et al. 2005) and 2003 (Burge et al. 2006). Given that SSM has been associated with OsHV in France beginning in 1993 (Renault et al. 1994a, 1994b), it is hypothesized that OsHV was involved in SSM in
Tomales Bay as early as 1993 when losses were first observed (Cherr \& Friedman 1998). A retrospective analysis of archived tissues for evidence of OsHV infection would test this hypothesis. Our observation of an association between presence of an oyster herpesvirus and mortality (Burge et al. 2006) suggests that further studies on the influence of OsHV on Pacific oyster seed survival are needed.

\section{ACKNOWLEDGMENTS}

The authors thank John Finger, Drew Alden, Bill Callahan, Larry Skidmore, Dick Poole, Chris Langdon, and Ted and Linda Kuiper for donation of oysters, technical assistance, and culture space at their farms; Jacqueline L. Mitchell for technical assistance, and Robyn M. Estes-Strenge and Jordan Watson for their editorial comments. This research was funded, in part, by a grant from the National Sea Grant College Program, National Oceanic and Atmospheric Administration, U.S. Department of Commerce, under grant number NA36RG0537, project number UCGS-25 through the California Sea Grant College and the California Department of Fish and Game, Marine Region. The views expressed herein are those of the authors and do not necessarily reflect the views of NOAA or any of its sub-agencies. The United States government is authorized to reproduce and distribute for governmental purposes.

\section{LITERATURE CITED}

Arzul, I., J. L. Nicolas, A. J. Davison \& T. Renault. 2001a. French scallops: a new host for Osterid Herpesvirus-1. Virology 290:342-349.

Arzul, I., T. Renault, C. Lipart \& A. J. Davison. 2001b. Evidence for interspecies transmission of oyster herpes virus in marine bivalves. J. Gen. Virol. 82:865-870.

Barbosa-Solomieu, V., L. Miossec, R. Vazquez-Juarez, F. AscencioValle \& T. Renault. 2004. Diagnosis of Ostreid herpesvirus 1 in paraffin-embedded archival samples using PCR and in situ hybridization. J. Virol. Methods 119:65-72.

Burge, C. A., F. J. Griffin \& C. S. Friedman. 2006. Mortality and herpesvirus infections of the Pacific oysters, Crassostrea gigas, in Tomales Bay, California. Dis. Aquat. Org. 72:31-43.

Calvo, L. M. R., G. W. Calvo \& E. M. Burreson. 2003. Dual disease resistance in a selectively bred eastern oyster, Crassostrea virginica, strain tested in Chesapeake Bay. Aquaculture 220:69-87.

Cheney, D. P., B. F. MacDonald \& R. A. Elston. 2000. Summer mortality of Pacific oysters, Crassostrea gigas (Thunberg): Initial findings on multiple environmental stressors in Puget Sound, Washington, 1998. J. Shellfish Res. 19:353-359.

Cherr, G. N. \& C. S. Friedman. 1998. Investigation of a mass mortality of pacific oysters, Crassotrea gigas, in Tomales Bay, California. California Sea Grant Report of Completed Projects 1994-1997 No. R-044. California Sea Grant College System, La Jolla, CA. pp. 167-172.

Cho, C. H. 1979. Mass mortalities of oyster due to red tide in Jinhae Bay in 1978. Bull. Korean Fish. Soc. 12:27-33.

Clegg, J. S., K. R. Ulinger, S. A. Jackson, G. N. Cherr, E. Rifkin \& C. S. Friedman. 1998. Induced thermotolerance and the heat shock protein-70 family in the Pacific oyster Crassostrea gigas. Mol. Mar. Biol. Biotechnol. 7:21-30.

Cole, B. E. 1989. Temporal and spatial patterns of phytoplankton production in Tomales Bay, California, U.S.A. Estuar. Coast. Shelf Sci. 28:103-115.

Comps, M. \& N. Cochennec. 1993. A herpes-like virus from the European oyster Ostrea edulis. J. Invertebr. Pathol. 62:201-203.
Degremont, L., E. Bedier, P. Soletchnik, M. Ropert, A. Huvet, J. Moal, J. F. Samain \& P. Boudry. 2005. Relative importance of family, site, and field placement timing on survival, growth, and yield of hatchery-produced Pacific oyster spat (Crassostrea gigas). Aquaculture 249:213-229.

Degremont, L., B. Ernande, E. Bedier \& P. Boudry. 2007. Summer mortality of hatchery-produced Pacific oyster spat (Crassostrea gigas). I. Estimation of genetic parameters for survival and growth. Aquaculture 262:41-53.

Friedman, C. S., J. H. Beattie, R. A. Elston \& R. P. Hedrick. 1991. Investigation of the relationship between the presence of a grampositive bacterial infection and summer mortality of the Pacific oyster, Crassostrea gigas, Thunberg. Aquaculture 94:1-15.

Friedman, C. S., A. Shamseldin, M. Pillai, P. G. Olin, G. N. Cherr, S. A. Jackson, E. Rifkin, K. R. Uhlinger \& J. S. Clegg. 1997. Summer mortality and the stress response of the Pacific oyster, Crassostrea gigas Thunberg. J. Shellfish Res. 16:335.

Friedman, C. S., R. M. Estes, N. A. Stokes, C. A. Burge, J. S. Hargrove, B. J. Barber, R. A. Elston, E. M. Burreson \& K. M. Reece. 2005. Herpes virus in juvenile Pacific oysters, Crassostrea gigas from Tomales Bay, California, coincides with summer mortality episodes. Dis. Aquat. Org. 63:33-41.

Gagnaire, B., H. Frouin, K. Moreau, H. Thomas-Guyon \& T. Renault. 2006. Effects of temperature and salinity on haemocyte activities of the Pacific oyster, Crassostrea gigas (Thunberg). Fish Shellfish Immunol. 20:536-547.

Glude, J. B. 1974. A summary report of Pacific coast oyster mortality investigations 1965 to 1972. Proceedings of the Third US-Japan Meeting on Aquaculture at Tokyo, Japan October 15-16 1974. pp. 1-28.

Hamdoun, A., D. P. Cheney \& G. N. Cherr. 2003. Phenotypic plasticity of HSP70 and HSP70 gene expression in the Pacific oyster (Crassostrea gigas): implications for thermal limits and induction of thermal tolerance. Biol. Bull. 205:160-169.

Hine, P. M., B. Wesney \& B. E. Hay. 1992. Herpesvirus associated with mortalities among hatchery-reared larval Pacific oysters, Crassostrea gigas. Dis. Aquat. Org. 12:135-142. 
Hine, P. M., B. Wesney \& P. Besant. 1998. Replication of herpes-like virus in larvae of the flat oyster Tiostrea chilensis at room temperature. Dis. Aquat. Org. 32:161-171.

Imai, T., K. Numachi, J. Oizumi \& S. Sato. 1965. Studies on the mass mortality of the oyster in Matsushima Bay. II. Search for the cause of mass mortality and the possibility to prevent it by transplantation experiment. The (in Japanese, English summary). Bull. Tohoku Regional Fish. Res. Lab. 25:27-38.

Judah, L. R. 2002. Phytoplankton community structure and seasonal succession in Tomales Bay, California. M.Sc. Thesis, San Francisco State University, San Francisco, California, USA. pp. 1-90.

Koganezawa, A. 1974. Present status of studies on the mass mortality of cultured oysters in Japan and its prevention. Proceedings of the Third US-Japan Meeting on Aquaculture at Tokyo, Japan October 15-16, 1974. pp. 29-34.

LeDeuff, R. M., T. Renault \& A. Gerard. 1996. Effects of temperature on herpes-like virus detection among hatchery-reared larval Pacific oyster Crassostrea gigas. Dis. Aquat. Org. 24:149-157.

Lipart, C. \& T. Renault. 2002. Herpes-like virus detection in infected Crassostrea gigas spat using DIG-labelles probes. J. Virol. Meth. 101:1-10.

Luna, L. G. (editor). 1968. Manual of histologic staining methods of the Armed Forces Institute of Pathology. 3rd ed. McGraw-Hill, New York. pp. 38-39.

Nicolas, J. L., M. Comps \& N. Cochennec. 1992. Herpes-like virus infecting Pacific oyster larvae, Crassostrea gigas. Bull. Eur. Assoc. Fish Pathol. 12:11.

Perdue, J. A., J. H. Beattie \& K. K. Chew. 1981. Some relationships between gametogenic cycle and summer mortality phenomenon in Pacific oyster (Crassostrea gigas) in Washington State. J. Shellfish Res. 1:9-16.

Perdue, J. A. 1983. The relationship between the gametogenic cycle of the Pacific oyster, C. gigas, and summer mortality phenomenon in strains of selectively bred oysters. Ph.D. Dissertation, University of Washington. $201 \mathrm{pp}$.

Ramsey, F. L. \& D. W. Schafer. (2002) The statistical sleuth: a course in methods of data analysis, 2nd ed. Pacific Grove: Duxbury. pp. $444-445$.
Renault, T., N. Cochennec, R. M. Le Deuff \& B. Chollet. 1994a Herpes-like virus infecting Japanese oyster (Crassostrea gigas) spat. Bull. Eur. Ass. Fish Pathol. 14:64-66.

Renault, T., R. M. Le Deuff, N. Cochennec \& P. Maffart. 1994b. Herpesviruses associated with mortalities among Pacific oyster, Crassostrea gigas, in France-comparative study. Revue. Med. Vet. 145:735-742.

Renault, T., R. M. Le Deuff, N. Cochennec, B. Chollet \& P. Maffart. 1995. Herpes-like viruses associated with high mortality levels in larvae and spat of Pacific oysters, Crassosstrea gigas: a comparative study, the thermal effects on virus detection in hatchery reared larvae, reproduction of the disease in axenic larvae. Vet. Res. 26:539-543.

Renault, T., R. M. Le Deuff, B. Chollet, N. Cochennec \& A. Gerard. 2000. Concomitant herpes-like infections in hatchery-reared larvae and nursery-cultured spat Crassostrea gigas and Ostrea edulis. Dis. of Aquat. Org. 42:173-183.

Renault, T. \& I. Arzul. 2001. Herpes-like infections in hatchery-reared bivalve larvae in Europe: specific viral DNA detection by PCR J. Fish Dis. 24:161-167.

Renault, T., C. Lipart \& I. Arzul. 2001. A herpes-like virus infects a non ostreid bivalve species: Virus replication in Ruditapes philippinarum larvae. Dis. Aquat. Org. 45:1-7.

Shaw, B. L. \& H. I. Battle. 1957. The gross and microscopic anatomy of the digestive tract of the oyster, Crassostrea virginica (Gmelin). Can. J. Zool. 35:325-347.

Sokal, R. R. \& F. J. Rohlf. 1995. Biometry: the principles and practice of statistics in biological research. 3rd ed. New York: W. H. Freeman and Co. 887 pp.

Soletchnik, P., C. Lambert \& K. Costil. 2005. Summer mortality of Crassostrea gigas (Thunberg) in relation to environmental rearing conditions. J. Shellfish Res. 24:197-208.

Thomas, C. (editor). 1997. Identifying marine phytoplankton. San Diego: Academic Press. 858 pp.

Utermohl, H. 1958. Toward the improvement of the quantitative phytoplankton method. Mitteleilungen-Internationale. Vereiningung fur Limnologie 9:1-38.

Zar, J. H. (editor). 1999. Biostatistical analysis. Upper Saddle River: Prentice Hall. pp. 128-129. 